\title{
Lower Motor Neuron Syndrome Following Radiotherapy
}

\author{
Sandra L. Horowitz and John D. Stewart
}

\begin{abstract}
SUMMARY: A 33 year old man developed bilateral leg weakness two years following radiotherapy to the pelvis and lower abdomen for the treatment of a seminoma. Clinical and electrophysiological examinations and nerve and muscle biopsies suggest that this is an example of either post-irradiation myelopathy selectively affecting the anterior horn cells in the lower spinal cord or a purely motor lumbo-sacral radiculopathy.
\end{abstract}

RÉSUMÉ: Nous rapportons le cas d'un patient de 33 ans qui, 2 ans après une radiothérapie du pelvis et de l'abdomen inférieur pour le traitement d'un séminome, développe une faiblesse bilatérale des jambes. Les études cliniques et électrophysiologiques, ainsi que des biopsies nerveuses et musculaires, suggèrent une myélopathie post-irradiation touchant sélectivement les cellules de la corne antérieure de la moelle inférieure ou une radiculopathie lombo-sacrée purement motrice.

Can.J. Neurol. Sci. 1983; 10:56-58

Patients with malignant neoplastic diseases who have received radiotherapy are subject to a number of paraneoplastic and post-radiation neurological syndromes as well as to complications directly due to the tumour itself (Henson, 1970). A rare type of post-radiation syndrome consists of a lower motor neuronopathy thought to result from damage to the anterior horn cells (Greenfield and Stark, 1948; Maier et al, 1969; Kristenson et al, 1977; Sadowsky et al, 1976; Rowland, 1979). We describe a patient with this syndrome and the investigations which further clarify this diagnostic entity.

\section{Case Report}

In 1977, a 33 year old man had a left trans-scrotal orchiectomy for a well differentiated seminoma. Post-operatively, he received 2,500 Rads to the whole pelvis and to the para-aortic area of the abdomen. In March 1979, a left upper quadrant retroperitoneal metastatic mass was resected, and the spleen, distal pancreas, and infiltrated lymph nodes were also removed. Radiotherapy ( $3,000 \mathrm{Rads})$ was given to the celiac area followed by a course of cyclophosphamide (total dose of $9 \mathrm{Grams}$ ). Nine months later he gradually developed asymmetrical bilateral leg weakness. There were no sensory, bladder or bowel symptoms, and no back pain. He was admitted to another hospital where he was found to have weakness of hip flexion, plantar-flexion and dorsi-flexion of the feet. Myelography, cerebrospinal fluid examination, bone scan and liver scan were normal. He was treated with prednisone $(40 \mathrm{mg} /$ day $)$ for two months with no improvement. His weakness gradually worsened for eight months, after which there was no further deterioration. At that time the neurological examination was normal except for the following findings. There was mild diffuse wasting in the legs, with normal muscle tone. Power was moderately and symmetrically reduced in the hamstrings, gastrocnemii and in the right tibialis anterior, and mildly reduced in the hip flexors and adductors, tibialis posterior and peronei. Tendon reflexes were normal and the plantar responses were flexor. Light touch, pinprick, two point discrimination, joint position and vibration sense were normal in the legs. Telephone follow-up with his family physician a year later confirmed no further deterioration in the patient's condition.

Laboratory investigations: The creatine phosphokinase was $43 \mathrm{IU} / \mathrm{L}$ (normal 36-199 IU/L) and the sedimentation rate $4 \mathrm{~mm} / \mathrm{hr}$ (Westergren). The cerebrospinal fluid (CSF) protein was $62 \mathrm{mg} / 100 \mathrm{ml}$, with a cell count of 1 red blood cell and 3 lymphocytes $/ \mathrm{ml}^{3}$. The CSF IgG was $1.2 \%$ (normal 1.4-2.5\%). Radiographs of the chest, thoracic, lumbar and sacral spine were normal, as were an intravenous pyelogram, technicium bone scan, and abdominal ultrasound. Computerized tomographic examinations of the abdomen and pelvis showed no evidence of tumour. A biopsy of the left gastrocnemius muscle showed moderate numbers of small angulated fibers with increased lactic dehydrogenase activity, several nuclear clumps and some degree of fiber type grouping, all indicative of neurogenic atrophy. A biopsy of the left sural nerve was normal to light and electron microscopy, although a quantitative examination of the fiber size and density was not performed.

Electrophysiological studies: The motor and sensory nerve potential amplitudes and conduction velocities were normal (Table 1). The electromyographic studies, performed with a concentric needle electrode demonstrated varying degrees of denervation and neurogenic changes in proximal and distal muscles supplied by roots L4-\$2 (Table 2).

\section{DISCUSSION}

Weakness in the legs beginning several months following radiotherapy that included the lower spinal cord, cauda equina and lumbo-sacral plexus has been described in patients treated for testicular tumours. The clinical features include atrophy, weakness and flaccidity in the legs, absent deep tendon reflexes and normal sensation (Greenfield and Stark, 1948; Maier et al, 1969). Bladder and bowel function may be normal, but cystometrographic studies have shown bladder hypotonicity in some patients. Kristenson et al (1977) have also described four such patients. Three had myelograms, two of which were normal, and the other showed arachnoiditis distal to the second lumbar vertebra. Electromyographic studies were limited to the extensor digitorum brevis muscles which showed evidence of denervation. In three patients the deterioration stabilized spontaneously approximately a year after the onset, while one patient worsened progressively. The only detailed electrophysiological study which has been reported in this syndrome is that of a patient who had radiotherapy to the neuraxis for a medulloblastoma. Motor and sensory nerve

From the Department of Neurology and Neurosurgery, McGill University, Division of Neurology, Montreal General Hospital, Montreal, Quebec.

Received June 10, 1982. Accepted for publication September 20, 1982.

Address reprint requests to Dr. John Stewart, Division of Neurology, Montreal General Hospital, 1650 Cedar Avenue, Montreal, Quebec, Canada $\mathrm{H} 3 \mathrm{G} 1 \mathrm{A4}$. 
TABLE 1

Nerve Conduction Studies

\begin{tabular}{|c|c|c|c|}
\hline \multicolumn{4}{|c|}{ M. } \\
\hline Maximum Motor Nerve Conduction & & & \\
\hline Posterior tibial & 42.8 & 46.5 & $39-59$ \\
\hline Peroneal & 48.7 & 51 & $36-64$ \\
\hline \multicolumn{4}{|l|}{ Distal Motor Latency (msec) } \\
\hline Posterior tibial & 4.4 & 5.7 & $4.0-8.1$ \\
\hline Peroneal & 5.1 & 5 & $3.8-7.1$ \\
\hline \multicolumn{4}{|c|}{ Compound Muscle Action Potential (mV) } \\
\hline Posterior tibial (abductor hallucis) & 12.5 & 12 & $8-23$ \\
\hline Peroneal (extensor digitorum brevis) & 7 & 6 & $3-12$ \\
\hline \multicolumn{4}{|l|}{ Sensory action potential (uV)* } \\
\hline Sural & 25 & 35 & $15-36$ \\
\hline Superficial peroneal & 10 & 12 & $8-25$ \\
\hline \multicolumn{4}{|c|}{ Maximum Sensory Nerve Conduction $(\mathrm{M} / \mathrm{sec})^{*}$} \\
\hline Sural & 46.6 & 53.8 & $40-64.2$ \\
\hline Superficial peroneal & 42 & 68 & $38.8-64.8$ \\
\hline
\end{tabular}

\begin{tabular}{|c|c|c|}
\hline \multicolumn{3}{|c|}{ Electromyographic Findings } \\
\hline Muscle & Right & Left \\
\hline Quadriceps & Normal & Normal \\
\hline Tibialis anterior & $\begin{array}{l}\text { Fibrillations } \\
\text { Positive sharp } \\
\text { waves (PSWs) } \\
\text { Neurogenic* }\end{array}$ & Normal \\
\hline Peroneus brevis & & $\begin{array}{l}\text { Fibrillations } \\
\text { PSWs } \\
\text { Neurogenic }\end{array}$ \\
\hline Gastrocnemius & $\begin{array}{l}\text { Fibrillations, } \\
\text { PSWs, Neurogenic }\end{array}$ & \\
\hline $\begin{array}{l}\text { Hamstrings; } \\
\text { Short head biceps }\end{array}$ & $\begin{array}{l}\text { Fibrillations, } \\
\text { PSWs, Neurogenic }\end{array}$ & Normal \\
\hline Semi-membranosus & & Neurogenic \\
\hline Gluteus medius & Neurogenic & Normal \\
\hline $\begin{array}{l}\text { Paraspinal, adjacent } \\
\text { 4th lumbar vertebra }\end{array}$ & & $\begin{array}{l}\text { Bizarre high } \\
\text { frequency } \\
\text { discharges }\end{array}$ \\
\hline
\end{tabular}

* Increased numbers of large $(>3 \mathrm{mV})$ and/or polyphasic ( 5 or more phases) motor units and reduced recruitment pattern.

conduction studies in the legs were normal, while a variety of muscles showed chronic partial denervation (Sadowsky et al, 1976).

Most authors have concluded that the probable site of damage in these patients is the anterior horn cell pool of the lower spinal cord, although Maier et al (1969) thought that the lumbo-sacral plexus may also be involved. In this regard, Klaua (1974) and Ashenhurst et al (1977) described patients with similar motor and reflex abnormalities in the legs, but who also had marked sensory involvement. At autopsy retroperitoneal fibrosis was seen in two patients, but the spinal cord, cauda equina, lumbar and sacral plex- uses were not specifically examined (Klaua, 1974). Ashenhurst et al (1977) concluded that the patients described by Greenfield and Stark (1948) and Maier et al (1969) as well as the patients described by themselves and by Klaua (1974), all probably had lumbo-sacral radiculopathy on the basis of retroperitoneal fibrosis.

Our patient also had involvement of motor nerves of the lower extremities, with no upper motor neuron signs. The normal motor nerve conduction velocities, in the presence of marked denervation and neurogenic changes, indicate either anterior horn cell disease or an axonal type of motor neuropathy. The neurogenic changes in the biopsy of the gastrocnemius muscle do not differentiate between these two possibilities. The normal sensory examination and intact reflexes, with normal sensory nerve conduction studies and sural nerve biopsy all indicate that if the patient had a neuropathy it must have been exclusively motor. This is rare, and it is therefore more likely that he had anterior horn cell degeneration. Furthermore, the lumbar paraspinal muscles showed bizarre high frequency discharges, a pattern seen most commonly in chronic partial denervation (Goodgold and Eberstein, 1977). This suggests that at least some of the lower motor neuron involvement was at, or proximal to, the dorsal primary rami of the spinal nerves. Therefore we propose that the major pathological process involves either anterior horn cells or motor roots, rather than the lumbo-sacral plexus.

The most common form of post-radiation myelopathy involves the cervical or thoracic spinal cord, usually runs an unremitting course, and the main clinical features are those of long tract involvement (Reagan et al, 1968; Dynes and Smedal, 1960; Pallis et al, 1961; Palmer, 1972; Lechevalier et al, 1973). Some patients also have signs of anterior horn cell or root abnormalities at the level of the myelopathy (Lechevalier et al, 1973; Palmer, 1977). At autopsy, severe damage of the long tracts has been confirmed (GodwinAusten et al, 1975; Kristenson et al, 1967). Nerve roots and nerve root ganglia were normal in all cases in which they 
were examined (Godwin-Austen et al, 1975). The anterior horn cells were usually normal, but two patients showed central chromatolysis (Godwin-Austen et al, 1975), and severe damage was present in another two (Kristenson et al, 1967; Lechevalier et al, 1973). Thus the anterior horn cells may not be as radiation-resistant as previously suggested (Kristenson et al, 1967).

One further possibility is that some factor other than radiation may be responsible for the lumbo-sacral lower motor neuron syndrome. Amyotrophic lateral sclerosis has been stated to occur as a remote manifestation of malignant disease (Brain et al, 1965). However, the restricted involvement in our patient, the lack of cortico-spinal tract signs, and the eventual lack of progression, makes this diagnosis unlikely. Anterior horn cell degeneration has been described in patients with lymphomas (Rowland and Schneck, 1964; Walton et al, 1968; Somasundaram et al, 1975). Some had involvement of the legs only and in some patients the weakness eventually stabilized or improved. Autopsy examination in one case revealed anterior horn cell loss without any other specific features (Somasundaram et al, 1975), while in another, an inflammatory infiltrate and viral particles were present in the areas of anterior horn cell degeneration (Walton et al, 1968). Several of these patients had not received radiotherapy. It is possible that our patient had such a para-neoplastic syndrome although, to date, this has been described mainly in patients with lymphomas. A patient with an occult bronchial oat-cell carcinoma who had severe neck and arm lower motor neuron type weakness and cervical sensory loss was found at autopsy to have marked damage to the anterior and posterior horns of the cervical spinal cord and to the hypoglossal nuclei. It was suggested that this patient had a non-metastatic carcinomatous encephalomyelitis (Adams and Richardson, 1970). Finally, a necrotizing myelopathy occurs as a rare, remote complication of cancer (Mancall and Rosales, 1964; Gray et al, 1980), but this severe disorder is quite unlike that which affected our patient.

In conclusion, a lower motor neuron syndrome may occur in some patients who have received radiotherapy to the lower spinal cord. This occurs most commonly after treatment for testicular malignancies. The electrophysiological studies in our patient provide further evidence that the site of damage is either the anterior horn cells of the lower spinal cord or the lumbar and sacral motor nerve roots, rather than the lumbo-sacral plexus.

\section{ACKNOWLEDGEMENTS}

We thank Dr. Calvin Melmed for permission to report a patient under his care and for helpful discussion, and Dr. M. Finlayson for the biopsy studies.

\section{REFERENCES}

Adams, R.D., and Richardson, E.P. (1970) Case records of the Massachusetts General Hospital, No. 42-1970. N. Eng. J. Med. 283: 806-814.

Ashenhurst, E.M., Quartey, G.R.C., Starreveld, A. (1977) Lumbo-sacral radiculopathy induced by radiation. Can. J. Neurol. Sci. 4: 259-263.

Brain, W.R., Croft, P.B., Wilkinson, M. (1965) Motor neurone disease as a manifestation of neoplasm. Brain 88: 479-500.
Dynes, J.B., and Smedal, M.I. (1960) Radiation myelitis. Am. J. Roentg. 83: 78-87.

Godwin-Austen, R.B., Howell, D.A., Worthington, B. (1975) Observations on radiation myelopathy. Brain 98: 557-568.

Goodgold, J. and Eberstein, A. (1977) Electrodiagnosis of Neuromuscular Diseases. Baltimore. Williams and Wilkins Company, 2nd edition: $\mathrm{p} 95$.

Gray, F., Hauw, J.J., Escourelle, R. et al. (1980) Necrotic myelopathies and neoplastic pathology. Three clinicopathological cases. Rev. Neurol. 136 (3): 235-246.

Greenfield, M.M. and Stark, F.M. (1948) Post-irradiation neuropathy. Am. J. Roentgenol. 60: 617-622.

Henson, R.A. (1970) Non-metastatic neurological manifestations of malignant disease. In Williams D: Modern Trends in Neurology, No. 5. London. Butterworths pp. 209-223.

Klaua, M. (1974) Radiogenic peripheral neuropathies following telecobalt irradiation in abdominal cavity. Radiobiol. Radiother. (Berl) 15(4): 459-464.

Kristenson, O., Melgard, B., Schiфt, A.V. (1977) Radiation myelopathy of the lumbo-sacral cord. Acta. Neurol. Scandinav. 56: 217-222.

Kristenson, K., Molin, B., Sourander, P. (1967) Delayed radiation lesions of the human spinal cord. Acta. Neuropathol. (Berl). 9: 34-44.

Lechevalier, B., Humeau, F., Houtteville, J.P. (1973) Myélopathies radiothérapiques (Hypertrophiantes). Rev. Neurol. (Paris) 129: 119-132.

Maier, J.G., Perry, R.H., Saylor, W., Sulak, M.H. (1969) Radiation myelitis of the dorsolumbar spinal cord. Radiology 93: 153-160.

Mancall, E.L., and Rosales, R.K. (1964) Necrotizing myelopathy associated with visceral carcinoma. Brain 87: 639-656.

Pallis, C.A., Louis, S., Morgan, R.L. (1961) Radiation myelopathy. Brain 84: 460-479.

Palmer, J.J. (1972) Radiation myelopathy. Brain 95: 109122.

Reagan, T.J., Thomas, J.E., Colby, M.Y. (1968) Chronic progressive radiation myelopathy. J.A.M.A. 203: 128 132.

Rowland, L.P. (1979) Motor neuron diseases: The Clinical Syndromes. In Mulder DW (editor): Diagnosis and Treatment of Amyotrophic Lateral Sclerosis. Boston. Houghton Mifflin Professional Publishers, pp. 7-27.

Rowland, L.P., Schneck, S. (1963) Neuromuscular disorders associated with malignant neoplastic disease. J. Chronic Dis. 16: 777-795.

Sadowsky, C.H., Sachs, E., Ochoa, J. (1976) Post-radiation motor neuron syndrome. Arch. Neurol. 33: 786-787.

Somasundaram, M., Cho, E.S., Posner, J.B. (1975) Anterior horn cell degeneration as a remote effect of lymphoma. Trans Am. Neurol. Assoc. 100: 144-148.

Walton, J.N., Tomlinson, B.E., Pearce, G.W. (1968) Subacute "poliomyelitis" and Hodgkin's disease. J. Neurol. Sci. 6: 435-445. 